\title{
Termite Digestibility and Water and Energy Contents Determine the Water Economy Index of Numbats (Myrmecobius fasciatus) and Other Myrmecophages
}

\author{
C. E. Cooper ${ }^{\star}$ \\ P. C. Withers \\ Zoology, School of Animal Biology, University of Western \\ Australia, Crawley, Western Austrialia 6009, Australia
}

Accepted 1/20/04 important predators of both termites and ants (Redford and Dorea 1984; Redford 1987). Despite their localised abundance, ants and termites are considered to have a low energy density and low digestibility (Redford and Dorea 1984) because of their high contents of chitin (5.1\%-16.5\%; Tihon 1946; Hulbert et al. 1981) and ash (up to 60\%; Redford and Dorea 1984). The low energetic return of a myrmecophagous diet has been related to the low basal metabolic rate (BMR) and low body temperature $\left(T_{\mathrm{b}}\right)$ of myrmecophagous mammals (McNab 1984, 2000). However, we are not aware of any study that directly measures the digestibility of termites by mammalian myrmecophages, although 59\% digestibility of ants has been measured for an exclusively myrmecophagous lizard, the thorny devil (Moloch horridus; Withers and Dickman 1985).

The first objective of this study was to measure the digestibility of termites for a strictly termitivorous marsupial, the numbat (Myrmecobius fasciatus). Numbats are small- to medium-sized (550-g) marsupials that are exclusively termitivorous and have anatomical specialisations (such as an elongated tongue, enlarged salivary glands, and a long, thin muzzle) typical of other myrmecophagous mammals (Griffiths 1968; Friend 1982). Numbats extract termites from shallow, subsurface soil galleries and feed on up to 25 different species, generally in proportion to their abundance and availability in the soil (Calaby 1960). Termites meet both the energy and water demands of the numbat, particularly during summer when free water would not be available.

The second objective of this study was to examine how the restricted diet of the numbat determines, for its particular digestibility, the ratio of water to energy turnover (water economy index [WEI]). Exclusively myrmecophagous animals such as the numbat provide the opportunity to investigate the interrelationships between diet, digestibility, and energy and water turnover because (in the absence of drinking) all food and water requirements are determined by a single dietary item, termites (or ants). The WEI expresses water turnover relative to energy turnover and is determined by input of water (metabolic water and preformed water), digestibility, and energy content of termites in the absence of drinking.

The final objective of this study was to use a simple model interrelating diet, digestibility, and WEI and to calculate the digestibility for termites by various free-living myrmecophages.
Approximately 22 species of placental, marsupial, and monotreme mammals specialise on a diet of ants and/or termites, and (apart from ants themselves) they are probably the most

\footnotetext{
Physiological and Biochemical Zoology 77(4):641-650. 2004. (C) 2004 by The

University of Chicago. All rights reserved. 1522-2152/2004/7704-3109\$15.00

* Corresponding author; e-mail ccooper9@pobox.une.edu.au.
} 


\section{Material and Methods}

Five captive adult male numbats from Perth Zoo were used for feeding trials. Four of the numbats were originally wild caught (Dryandra Woodland: $31^{\circ} 46^{\prime} \mathrm{S}, 117^{\circ} 1^{\prime} \mathrm{E}$ ) and had been in captivity for 2, 6, 6, and $10 \mathrm{yr}$. The fifth numbat was a 6 -yr-old individual born in captivity. The numbats were usually housed in large outdoor wire enclosures, where they were exposed to natural weather and photoperiod for South Perth, Western Australia $\left(31^{\circ} 58^{\prime} \mathrm{S}, 115^{\circ} 51^{\prime} \mathrm{E}\right)$. They were maintained on an artificial diet of low-lactose milk powder, baked termite mound, vitamins, and termites.

Coptotermes (probably Coptotermes acinaciformis raffrayi) and Nasutitermes (probably Nasutitermes exitiosus) termites were collected from a mixed jarrah (Eucalyptus marginata) and marri (Corymbia calophylla) forest near Jarrahdale $\left(32^{\circ} 20^{\prime} \mathrm{S}\right.$, $\left.116^{\circ} 3^{\prime} \mathrm{E}\right)$ southeast of Perth, Western Australia, in large metal drums filled with lengths of karri (Eucalyptus diversicolor) timber. Termites from different drums were combined and stored frozen until they were fed to the numbats.

During feeding trials, the numbats were housed in separate indoor enclosures $(2.5 \mathrm{~m} \times 5 \mathrm{~m})$ with a sand (four individuals) or concrete (one individual) substrate. They were fed a diet of pure Coptotermes for three consecutive weeks, then Nasutitermes for $1 \mathrm{wk}$, and then Coptotermes again for the last $5 \mathrm{~d}$. One numbat refused to eat Nasutitermes, so $n=4$ for measurements of passage time and Nasutitermes digestibility. The numbats were fed twice daily, at approximately 0700 and 1300 hours and were weighed $( \pm 0.1 \mathrm{~g})$ weekly. Termites were provided in a bowl that was placed on a wooden stand to prevent accidental ingestion of debris and loss of any termites flicked out of the bowl during feeding. The termites given to each numbat were weighed (Sartorius Handy Balance; $\pm 0.0001 \mathrm{~g}_{\text {wet }}$ ), along with a sample of termites that was later dried to a constant mass and then reweighed to determine the water content of the termites eaten by the numbats. Any uneaten termites were collected and frozen for subsequent determination of dry weight. All faeces were collected in the evening (approximately 1700 hours) after the numbats had retired to their nest boxes for the night. Faeces were also collected at 1300 hours daily during the measurement of passage time (i.e., when numbats were switched from Coptotermes to Nasutitermes and back again). Data from the first $4 \mathrm{~d}$ of feeding trials were discarded (along with the $3 \mathrm{~d}$ when changing from one termite species to another) to enable the numbats to become accustomed to the termite diet, to acclimate to the artificial indoor conditions, and to ensure that any other previous food material had been eliminated from their digestive system.

Termite samples, uneaten termites, and numbat faeces were dried in a Labmaster drying oven at $45^{\circ} \mathrm{C}$ to a constant mass. The dry matter ingested each day by each numbat was calculated as $\mathrm{g}_{\text {wet }}$ termites $\times(1-$ fraction of water in termite sample) $-g_{\text {dry }}$ uneaten termites; data were summed for morn- ing and evening feeds. Eight (Nasutitermes) and 10 (Coptotermes) random samples of 200 individual termites were counted and the proportion of soldiers to workers determined. These samples were dried to a constant mass, and the dry mass of an individual termite was calculated as the mean (sample mass/ 200). Energy and ash contents of 29 dry samples of Coptotermes and eight samples of Nasutitermes were determined by bomb calorimetry, using a Gallenkamp ballistic bomb calorimeter calibrated with benzoic acid as a standard (after Cooper et al. 2002). Energy ingested by each numbat was calculated as the dry mass of food eaten each day multiplied by the mean total energy content of the termites.

Bomb calorimetry was also used to determine the ash-free energy content of dry faecal samples collected from each numbat. The dry mass of organic faecal material produced each day was determined by weighing the dry sample, placing it in a muffle furnace at $600^{\circ} \mathrm{C}$ for $12 \mathrm{~h}$, and then subtracting the remaining mass of ash; the dry mass of faeces could not be determined directly because sand adhered to the faeces. The total daily energy lost as faeces was calculated as the mean energy content of the faeces multiplied by the dry mass produced by each numbat each day. The energy $(E)$ digestibility of termites by numbats was calculated as $\left(E_{\text {in }}-E_{\text {out }}\right) / E_{\text {in }}$ (Maynard and Loosli 1969; Withers 1978, 1982).

For an animal of constant body mass, the average daily metabolic rate (ADMR) is equivalent to metabolisable energy, which is the ingested energy minus the energy lost as both faeces and urine. Urinary energy loss is typically low (approximately $2 \%$ of ingested energy) for small mammals (Grodzinski and Wunder 1975; Withers 1978), so it can even be ignored in calculations of ADMR. The ADMR of captive numbats was calculated for feeding trials as (daily energy ingested - 2\%) (faecal energy of the following day) for a period of $1 \mathrm{wk}$ when body mass remained constant for all individuals.

Passage time was determined by changing the diet from one species of termite to the other and examining dried faeces (collected at 1300 and 1700 hours daily) under a binocular dissecting microscope to score the proportions of mandibles from Coptotermes and Nasutitermes in counts of 200 mandibles. The percentage of the new (marker) termite species was then calculated for each time.

The inorganic debris (mainly soil) ingested by wild numbats while feeding was estimated for eight numbat scats collected opportunistically at Dryandra Woodland. The dried scats were inspected to ensure that there was no soil or other particles adhering to the outside, and they were weighed. The organic content was combusted in the muffle furnace (as for captive numbat faeces), and then the remaining ash was reweighed. The ash content of faeces attributable to termites was measured for faeces (38 samples) from the single captive numbat that was kept on concrete, not sand (which avoided ash content because of adhering sand particles). The ash from termites (\%) was subtracted from the total remaining ash of the wild numbat 
Table 1: Characteristics of termite species used in feeding trials

\begin{tabular}{lcccr}
\hline & Coptotermes & $n$ & Nasutitermes & $n$ \\
\hline Workers $(\%)$ & $96 \pm 1.1$ & 10 & $97 \pm 1.1$ & 8 \\
Dry mass $(\mathrm{mg})$ & $.96 \pm .099$ & 10 & $.91 \pm .046$ & 8 \\
Water content $(\%)$ & $78.0 \pm .36$ & 41 & $76.7 \pm 3.09$ & 13 \\
Ash content $(\%)$ & $5.8 \pm .31$ & 29 & $7.5 \pm 1.10$ & 8 \\
Energy content $\left(\mathrm{kJ} \mathrm{g}_{\text {dry }}^{-1}\right)$ & $23.1 \pm .19$ & 29 & $22.7 \pm .36$ & 8 \\
\hline
\end{tabular}

faeces, and the remainder was considered to be from ingested soil. This mass of ingested soil was expressed relative to the organic content of the faeces (i.e., $g$ soil $\mathrm{g}^{-1}$ organic matter). Daily ingestion of soil was then estimated from the organic matter content of the faeces that was calculated from the field metabolic rate (FMR; $269 \mathrm{~kJ} \mathrm{~d}^{-1}$; Cooper et al. 2003), the energy content of the food (23 kJ g organic matter ${ }^{-1}$; this study), and digestibility (both $81 \%$ and 64\%; this study), as $(269 / 23) \times(100 /$ digestibility $) \times\left(\right.$ g soil $g$ organic matter $\left.{ }^{-1}\right)$.

All values are presented as mean \pm SE unless otherwise stated. Changes in body mass were analysed with repeatedmeasures ANOVA (rmANOVA); $t$-tests (with test and correction for equality of variances) were used to examine differences in the characteristics of the two termite species. Paired $t$-tests (using means of the daily values from each numbat) were used to determine differences in the response of the numbats to the different termite diets, and rmANOVA was used to examine daily variability in digestibility, using statistiXL, version 1.1 . Digestibility refers to energy digestibility due to the difficulty in determining the total mass of faeces (including inorganic material) without adhering sand, which means that only the organic (and energy) content of the faeces could be determined accurately.

\section{Results}

\section{Termites}

Coptotermes and Nasutitermes samples contained 96\%-97\% workers (Table 1). There was no significant difference in the dry mass $\left(t_{7}=7.7, P=0.279\right)$, energy $\left(t_{35}=1.1, P=0.300\right)$, water $\left(t_{11.7}=0.4, P=0.736\right)$, or ash $\left(t_{10.5}=1.5, P=0.179\right)$ content of Coptotermes and Nasutitermes.

\section{Digestion}

The body mass of the five numbats did not change significantly (rmANOVA $\left.F_{2,3}=1.0, P=0.524\right)$ during the 3 wk of Coptotermes feeding trials $(520 \pm 32.2$ to $548 \pm 21.7 \mathrm{~g})$. During the week of feeding on Nasutitermes, the mass of the four numbats decreased significantly (rmANOVA $F_{3,4}=16.5, P=0.027$ ) from $552 \pm 27.4$ to $523 \pm 26.6 \mathrm{~g}$.

The numbats had a significantly higher rate of dry mass consumption for Nasutitermes than Coptotermes (paired $t_{3}=$ 3.45, $P=0.04$ ), although the difference in daily energy intake for Nasutitermes and Coptotermes was not significant (paired $t_{3}=3.0, P=0.059$; Table 2). There was no significant difference between the ash-free energy content of faeces for the two diets, which were $21.7 \pm 0.20 \mathrm{~kJ} \mathrm{~g}_{\text {dry }}^{-1}$ when feeding on $\mathrm{Nasu}$ titermes and $21.6 \pm 0.14 \mathrm{~kJ} \mathrm{~g}_{\text {dry }}^{-1}$ when feeding on Coptotermes. The numbats did produce significantly more organic faecal material $\left(t_{3}=5.8, P=0.01\right)$ when feeding on Nasutitermes than when feeding on Coptotermes.

Termite digestibility, calculated from the total energy intake and total faecal energy loss for each numbat then averaged, was higher for Coptotermes (83\% over $16 \mathrm{~d}$ ) than for Nasutitermes (63\% over $4 \mathrm{~d}$; Table 2 ). Digestibility calculated from the daily values averaged for each numbat and then averaged across all numbats was similar for Coptotermes ( $81 \%$ for five numbats over $16 \mathrm{~d}$ ) and Nasutitermes (62\% for four numbats over $4 \mathrm{~d}$ ). When calculated as the daily energy intake minus the faecal energy loss of the following day (because passage time is 20$30 \mathrm{~h}$ ), digestibility averaged for each numbat and then averaged across all numbats was again similar for Coptotermes $(81 \%)$ and Nasutitermes (64\%). Clearly, the method of calculation has little effect on the determination of digestibility for each termite species, so all subsequent calculations are based on values calculated by the last offset method. Digestibility is significantly higher (paired $t$-test: $t_{3}=6.2, P=0.009$ ) for Coptotermes than

Table 2: Mass $\left(\mathrm{g} \mathrm{d}^{-1}\right)$ and energy $\left(\mathrm{kJ} \mathrm{d}^{-1}\right)$ ingested and in faeces and energy digestibility $(\%)$ of the diet (mean \pm SE) for numbats feeding on Coptotermes $(n=5)$ and Nasutitermes $(n=4)$ termites

\begin{tabular}{lcc}
\hline & Coptotermes & Nasutitermes \\
\hline Termites ingested $\left(\mathrm{g}_{\text {dry }} \mathrm{d}^{-1}\right)$ & $12.8 \pm 1.06$ & $14.5 \pm 1.53$ \\
Organic content of faeces $\left(\mathrm{g}_{\text {dry }} \mathrm{d}^{-1}\right)$ & $2.7 \pm .41$ & $5.7 \pm .68$ \\
Energy ingested $\left(\mathrm{kJ} \mathrm{d}^{-1}\right)$ & $307 \pm 27.6$ & $330 \pm 34.8$ \\
Energy in faeces $\left(\mathrm{kJ} \mathrm{d}^{-1}\right)$ & $58 \pm 9$ & $123 \pm 16.5$ \\
Total energy digestibility $(\%)$ & $83 \pm 1.4$ & $63 \pm 2.2$ \\
Average daily energy digestibility $(\%)$ & $81 \pm 1.2$ & $62 \pm 2.2$ \\
Offset daily energy digestibility $(\%)$ & $81 \pm 1.2$ & $64 \pm 3.3$ \\
\hline
\end{tabular}


for Nasutitermes. Day of measurement also had no affect on termite digestibility for Coptotermes ( $r m$ ANOVA $P=0.414$ ) or Nasutitermes $(P=0.066)$.

ADMR was $258 \pm 25.1 \mathrm{~kJ} \mathrm{~d}^{-1}$ for numbats feeding on Coptotermes. Captive numbats were calculated to consume 13,333 individual Coptotermes termites each day $\left(12,800 \mathrm{mg}_{\text {dry }}\right.$ ingested, $0.96 \mathrm{mg}_{\text {dry }}$ individual termite ${ }^{-1}$ ) or 15,934 Nasutitermes termites each day $\left(14,500 \mathrm{mg}_{\text {dry }}\right.$ ingested, $0.91 \mathrm{mg}_{\text {dry }}$ individual termite $\left.^{-1}\right)$.

\section{Passage Time}

Mandibles of the new (marker) termite species first appeared in the faeces $\leq 6 \mathrm{~h}$ after the first meal. By about $12 \mathrm{~h}, 50 \%$ of mandibles were from the marker termites, and by $20-30 \mathrm{~h}$, only the marker species was present. This pattern was the same when diets were switched from Coptotermes to Nasutitermes and vice versa (Fig. 1). Faeces collected from individual numbats on the same day varied in appearance and content (Fig. 2), with some pellets consisting of mostly chitinous termite parts (mandibles, head capsules, legs) and others consisting of mostly finely ground matter, with very few recognisable termite parts.

\section{Ingestion of Debris}

The ash content of faeces from wild numbats was $55 \% \pm$ $2.9 \%$. The ash content of faeces attributed to termites only was $13.5 \% \pm 0.31 \%$ (measured for the captive numbat kept on a concrete substrate), so the nontermite ash content for wild numbat faeces is $47 \% \pm 2.5 \%$. Wild numbats were calculated to ingest $1.1 \mathrm{~g}$ of inorganic debris per gram of organic matter in the faeces.

The mass of organic matter in the faeces of wild numbats was calculated from FMR as $2.5 \mathrm{~g} \mathrm{~d}^{-1}$ (81\% digestibility) to $4.6 \mathrm{~g} \mathrm{~d}^{-1}$ (64\% digestibility). Therefore, the ingested inorganic debris was estimated as $1.1 \times$ mass of organic matter, that is, 2.7-5.1 $\mathrm{g} \mathrm{d}^{-1}$, respectively, with a mean of $3.9 \mathrm{~g} \mathrm{~d}^{-1}$.

\section{Discussion}

Termite-eating mammals such as the numbat are unusual not only from the viewpoint of their specialised anatomy and physiology but also for the opportunity they provide to investigate closely the interrelationships between composition of the diet, its digestibility, and the energy and water turnover of the termitivore. We first discuss the digestibility of termites by numbats. We then examine how the termite diet of the numbat determines the ratio of water and energy turnover for a particular digestibility, for both captive and free-ranging numbats. Last, we extend the interrelationship of diet, digestibility, and WEI to calculate digestibility by other myrmecophages.

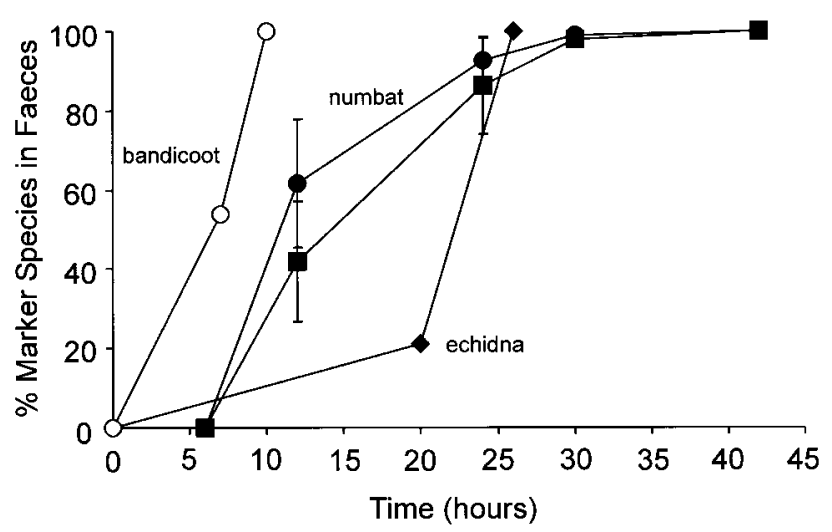

Figure 1. Passage time (hours after first feeding) of Coptotermes (filled squares; $n=5$ ) and Nasutitermes (filled circles; $n=4$ ) through the digestive system of the numbat $(n=4$, values $\pm \mathrm{SE})$, calculated as the proportion of mandibles of the marker termite in counts of 200 mandibles in numbat faeces and for the echidna (filled diamonds) and northern brown bandicoot (open circles; data from Griffiths 1968).

\section{Termite Digestion by Numbats}

Termites. The compositions of Coptotermes and Nasutitermes termites examined in this study (Table 1) are typical of values for termites in general. Water contents $(76.7 \%$ and $78.0 \%)$ were similar to those for other termite species (66\%-80\%; Redford and Dorea 1984; Abensperg-Traun and de Boer 1992; Oyarzun et al. 1996; Williams et al. 1997; Seymour et al. 1998), ants (40\%-80\%; Griffiths 1965; Withers and Dickman 1995), and a generalised insect $(70 \%-75 \%$; Bell 1990). The total energy contents $\left(23.1 \mathrm{~kJ}\right.$ and $22.7 \mathrm{~kJ} \mathrm{~g} \mathrm{~g}_{\text {dry }}^{-1}$ ) were typical of most biological materials (Cummins and Wuycheck 1971; d'OleireOltmanns 1977) and values previously determined for termites (17-22.7 kJ g gry; Abensperg-Traun and de Boer 1992; Williams et al. 1997; Seymour et al. 1998), ants (20-40 kJ g dry ${ }_{\text {dry }}^{-1}$ Withers and Dickman 1995), and insects in general (12-29.7 $\mathrm{kJ} \mathrm{g} \mathrm{g}_{\text {dry }}^{-1}$; Bell 1990). The ash content of termites is highly variable, ranging from 6\% to 60\% (Redford and Dorea 1984), with soileating termites generally having a much higher ash content (up to $60 \%)$ than wood-eating termites $(6 \%-10 \%)$. The ash content of our wood-eating Coptotermes and Nasutitermes (5.8\%-7.5\%) is typical of other wood-eating termites and similar to a generalised insect (5\%; Bell 1990).

Passage Time. The numbats' passage time for termites $(50 \%$ of mandibles were of the marker species by $12 \mathrm{~h}$ and $100 \%$ after 20-30 h; Fig. 1) is much slower than that of the omnivorous bandicoot (Isoodon macrourus) when fed termites (54\% by only $7 \mathrm{~h}$ after ingestion and $100 \%$ by $10 \mathrm{~h}$; Griffiths 1965). For the myrmecophagous echidna (Tachyglossus aculeatus), passage time was also slow (20\% by $21 \mathrm{~h}$ after ingestion and $100 \%$ by $26 \mathrm{~h}$; Griffiths 1968), which may in part reflect its low $T_{\mathrm{b}}$ and metabolic rate. Termite specialists, such as the numbat and 

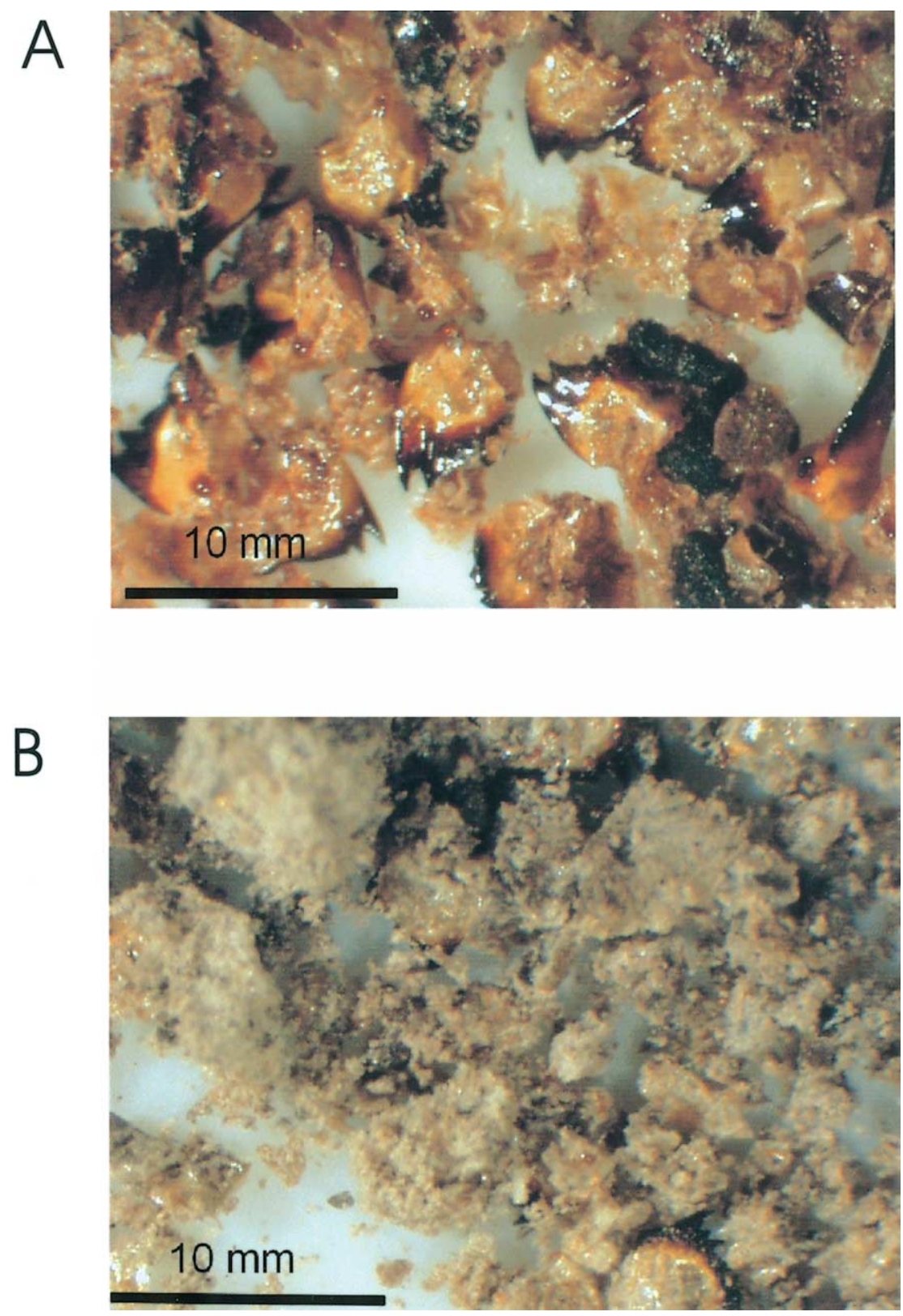

Figure 2. Varying proportions of termite parts $(A)$ and ground matter $(B)$ from two faecal pellets produced by a captive numbat consuming only termites.

echidna, may have a slow passage time to improve the digestibility of termites, but this would decrease the rate of food ingestion and thereby compromise the rate of energy acquisition from the diet.

Despite its anatomical simplicity (Griffiths 1968; Hume 1982), the numbat's digestive system appears to sort digesta. Calaby (1960) noted that faeces collected from wild, free-living numbats differed in appearance and content, with varying pro- portions of termite parts and ground matter. For wild numbats, this might be due to their foraging in different areas, and therefore the ingestion of debris and species of termites would vary between individuals and between feeding bouts. However, in this study, the captive numbats were fed only termites, with no debris, and so any differences in faecal appearance and content (Fig. 2) must be due to sorting by the digestive system. This sorting presumably occurs through differences in the rate of 
movement of different size and density particles and possibly selective retention of smaller, nonchitinous matter to improve energy assimilation.

Digestibility. The digestibility of termites is of ecological importance because it determines the amount of the ingested energy that can be metabolised and also because it links the water and energy turnovers for termitivorous animals to determine their relative water economy. However, there is surprisingly little available information about animals' digestibility of termites. Our measurements for numbats are the first that we are aware of.

The higher digestibility of Coptotermes ( $81 \%$ ) compared with Nasutitermes (64\%) is due to the higher dry mass of faeces produced from the Nasutitermes diet, not a higher energy content of faeces. Presumably, less of Nasutitermes' organic content is digestible because ash content is similar for both species; Nasutitermes might have more chitin than Coptotermes and hence might be less digestible. The reduced digestibility of $\mathrm{Na}$ sutitermes was associated with a slight reduction in body mass by all numbats on that diet.

Captive numbats' relatively high $(64 \%-81 \%)$ digestibility of termites is similar to that calculated for other myrmecophagous animals. This is despite the numbat's unspecialised digestive system, which is similar to that of carnivorous marsupials (Griffiths 1968; Hume 1982). Numbats lack any obvious specialisation of the stomach (e.g., a large muscular wall, cornified stratified epithelium, or keratinised "teeth") for grinding termites and managing large quantities of ingested dirt, such as seen in other myrmecophagous mammals, including aardvarks (Orycteropus after), pangolins (Manis sp.), anteaters (Myrmecophagidae), armadillos (Dasypodidae), and echidnas (Owen 1857; Murie 1875; Forbes 1882; Weber 1891; Bequaert 1922; cited by Griffiths 1968). The need for the stomach to break up termites may be reduced for the numbat because it does use its teeth (reduced but still present) to chew its food partially (Fleay 1942; C. Cooper, personal observation; T. Friend, personal communication). Chewing is not possible for those other myrmecophagous mammals with highly specialised jaws and extremely reduced or absent teeth (e.g., anteaters and echidnas; Griffiths 1968; Brainerd 1999; Naples 1999).

Average Daily Metabolic Rate. ADMR measured for numbats in captivity would be expected to be lower than the FMR of wild, free-living numbats because of reduced activity levels and reduced thermoregulatory costs in captivity, but for captive numbats, ADMR was remarkably similar $\left(258 \pm 25.1 \mathrm{~kJ} \mathrm{~d}^{-1}\right)$ to the FMR of $269 \pm 30.5 \mathrm{~kJ} \mathrm{~d}^{-1}$ (Cooper et al. 2003). This suggests that captive numbats held in a small enclosure can have a similar energy requirement and activity level as wild numbats. The BMR of captive and wild numbats is also the same (Cooper 2004); thus, captivity seems to have no effect on the basic metabolic physiology of the numbat.
If the termites contain $77.7 \%$ water and an individual termite weighs $0.93 \mathrm{mg}_{\mathrm{dry}}$, then wild numbats must ingest 21,660 termites $\mathrm{d}^{-1}$ to account for their preformed water intake $(70.2$ $\left.\mathrm{mL} \mathrm{d}^{-1}\right)$. Values for captive $\left(13,333-15,394\right.$ termites $\left.\mathrm{d}^{-1}\right)$ and wild numbats are similar to those estimated previously $(15,000$ 20,000 termites $\mathrm{d}^{-1}$ ) for captive numbats by Friend (1987) but considerably more than the $10,000 \mathrm{~d}^{-1}$ estimated for a single captive female numbat by Fleay (1942).

WEI and Digestibility. WEI is water turnover relative to energy turnover. In the absence of drinking, mammals obtain water only from metabolic water production (MWP) and from their food. The preformed water content, digestibility, and energy content of different foods (along with MWP) collectively determine the WEI (Fig. 3). WEI can be determined for different combinations of water content, digestibility, and energy content of a termite diet because $\mathrm{WEI}=$ water content/ [solid content $\times$ (energy content $\times$ digestibility/100)] + (0.025)MWP. This equation can be rearranged to calculate digestibility from WEI. We can use this relationship between diet, digestibility, and WEI to calculate WEI for captive numbats and WEI for free-living numbats (and other specialist myrmecophages) because all food and nearly all water requirements are determined by a single dietary item, termites (or ants).

Captive numbats feeding on Coptotermes consumed $12.8 \mathrm{~g}_{\text {dry }}$ $\mathrm{d}^{-1}\left(307 \mathrm{~kJ} \mathrm{~d}^{-1}\right)$, which with an $81 \%$ digestibility yielded an ADMR of $248 \mathrm{~kJ} \mathrm{~d}^{-1}$. With a water content of $78 \%$, Coptotermes provided the numbats with $45.3 \mathrm{~mL} \mathrm{H}_{2} \mathrm{O}$, and there was a further gain of $6.2 \mathrm{~mL}$ from MWP, so that total water turnover rate (WTR) was $51.5 \mathrm{~mL} \mathrm{~d}^{-1}$. Therefore, in the absence of drinking, the WEI is $0.20(51.5 / 248)$. The numbats consumed

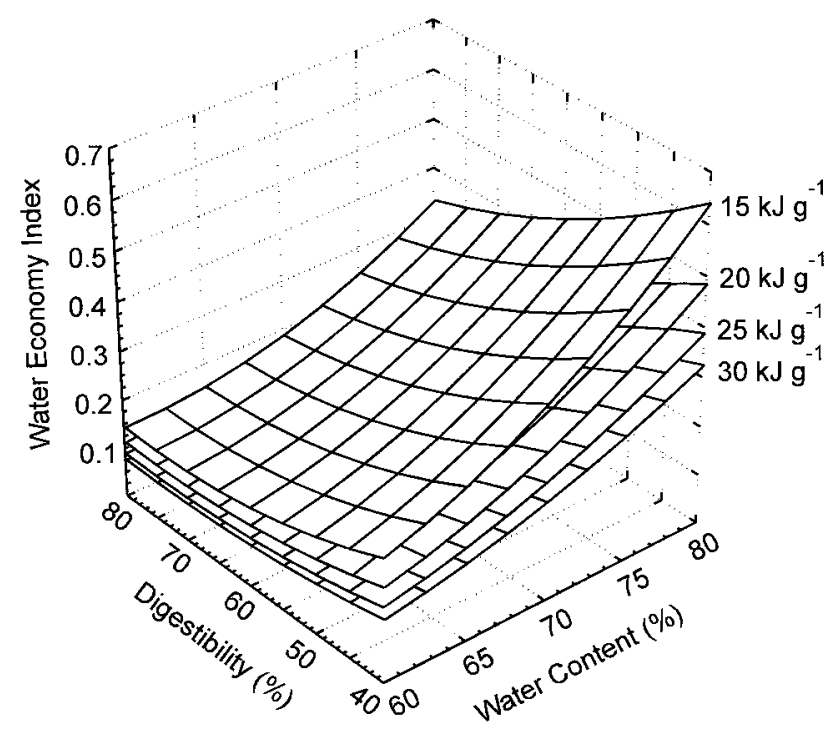

Figure 3. Theoretical water economy index for a termite diet of varying water content $(\%)$, digestibility $(\%)$, and energy content $\left(\mathrm{kJ} \mathrm{g}_{\mathrm{dry}}^{-1}\right)$. 
$14.5 \mathrm{~g}_{\text {dry }}$ of Nasutitermes per day $\left(330 \mathrm{~kJ} \mathrm{~d}^{-1}\right)$ and ADMR was $210 \mathrm{~kJ} \mathrm{~d}^{-1}$ (64\% digestibility). The $76.5 \%$ water content of Nasutitermes provided $47.7 \mathrm{~mL} \mathrm{H}_{2} \mathrm{O}$, with a further $5.1 \mathrm{~mL}$ from MWP, so that total WTR was $52.8 \mathrm{~mL} \mathrm{~d}^{-1}$. The WEI for a Nasutitermes diet was 0.25 (52.8/210). These WEI values for captive numbats are higher than expected for an animal-based diet of 0.07-0.17 (Nagy and Peterson 1988) because of the similar water content but relatively low digestibility of termites. If the captive numbats drank, then their WEI would be even higher.

If the WEI and energy and water contents of the diet are known, then we can calculate digestibility (Fig. 3). However, it is important that the WEI is calculated using the correct field water turnover rate (FWTR). For studies where FWTR is measured isotopically, the passive exchange across the lungs of unlabelled ambient water vapour with labelled body water must be accounted for because it leads to the overestimation of the actual FWTR (Nagy and Costa 1980). For wild, free-living numbats, FWTR (measured by tritiated water; Cooper et al. 2003) is $84.1 \mathrm{~mL} \mathrm{H}_{2} \mathrm{O} \mathrm{d}^{-1}$. However, this includes MWP, water obtained from ingesting damp soil, and the passive exchange of inspired unlabelled water vapour with labelled body water. MWP was calculated (as $6.72 \mathrm{~mL} \mathrm{H}_{2} \mathrm{O} \mathrm{d}^{-1}$ ) from FMR (Cooper et al. 2003), assuming $25 \mathrm{mg} \mathrm{kJ}^{-1}$ of metabolisable energy (Withers 1992; Seymour et al. 1998). We calculate that numbats ingest approximately $4 \mathrm{~g}$ of soil daily, and if the soil moisture content was $50 \%$, this would be $2 \mathrm{~mL} \mathrm{H}_{2} \mathrm{O} \mathrm{d}^{-1}$. The extent of passive exchange of water vapour across the lungs can be estimated from the ambient water vapour content and the animal's ventilation rate (Nagy and Costa 1980). We estimate from typical summer ambient and burrow temperatures and relative humidities (at the location FMR was measured; Cooper 2004) and ventilation data for numbats (Cooper and Withers 2004) that this exchange is approximately $5.2 \mathrm{~mL} \mathrm{~d}^{-1}$. Thus, only 70.2 $\mathrm{mL}$ of the $84.1 \mathrm{~mL} \mathrm{H}_{2} \mathrm{O} \mathrm{d}^{-1}$ is ingested as preformed water in termites. The WEI for wild, free-living numbats, measured by doubly labelled water (and corrected for passive exchange), was 0.29 (78.9/269; Cooper et al. 2003), which is higher than that for captive numbats consuming Coptotermes (0.20) or Nasutitermes $(0.25)$ and is also higher than expected for a general animal-based diet (Nagy and Peterson 1988).

The wild numbats' FWTR of $78.9 \mathrm{~mL} \mathrm{H}_{2} \mathrm{O} \mathrm{d}^{-1}$ includes 72.2 $\mathrm{mL}$ of preformed water $(78.9-\mathrm{MWP}$ of $6.7 \mathrm{~mL}$ ), which (for termites containing $77.7 \%$ water) would be accompanied by $20.7 \mathrm{~g}$ of solids. If these termites contain $22.9 \mathrm{~kJ} \mathrm{~g}_{\text {dry }}^{-1}$, then numbats would ingest $475 \mathrm{~kJ} \mathrm{~d}^{-1}$. With a measured FMR of $269 \mathrm{~kJ} \mathrm{~d}^{-1}$, the digestibility of termites by wild numbats would be $57 \%(269 / 509)$. After accounting for a further $2 \mathrm{~mL}$ of water from ingesting moist soil, a digestibility of $58 \%$ is required for the high WEI of wild numbats (0.29) to fit the theoretical WEI for a termite diet. This is lower than for captive numbats eating termites $(64 \%-81 \%)$.

\section{Termite Digestion by Other Myrmecophages}

There are few estimates of digestibility for myrmecophages. Energy digestibility was measured as 59\% for ants by thorny devils (Moloch horridus; Withers and Dickman 1995). Seymour et al. (1998) calculated a digestibility of 79\% for Namib golden moles (Eremitalpa granti namibensis) eating termites and insect larvae. We extend our analysis of relationships between diet, digestibility, and WEI from the numbat to calculate digestibility for other free-living myrmecophages, using our model of these relationships (Fig. 4). However, we cannot account for their passive exchange of unlabelled ambient water vapour with labelled body water and the ingestion of moist debris because these estimations of errors require unavailable information of tidal volumes, ambient temperature and humidity, and debris ingestion rates. Therefore, our calculated digestibilities will be slightly underestimated (for numbats, the uncorrected digestibility was $53 \%$ rather than $58 \%$ ).

The thorny devil that eats ants has a WEI of 0.11 (Withers and Bradshaw 1995) that, for ants containing $60 \%$ water and $30 \mathrm{~kJ} \mathrm{~g}_{\text {dry }}^{-1}$ is accounted for by the same digestibility as directly measured, of 59\% (Withers and Dickman 1995). Silky anteaters

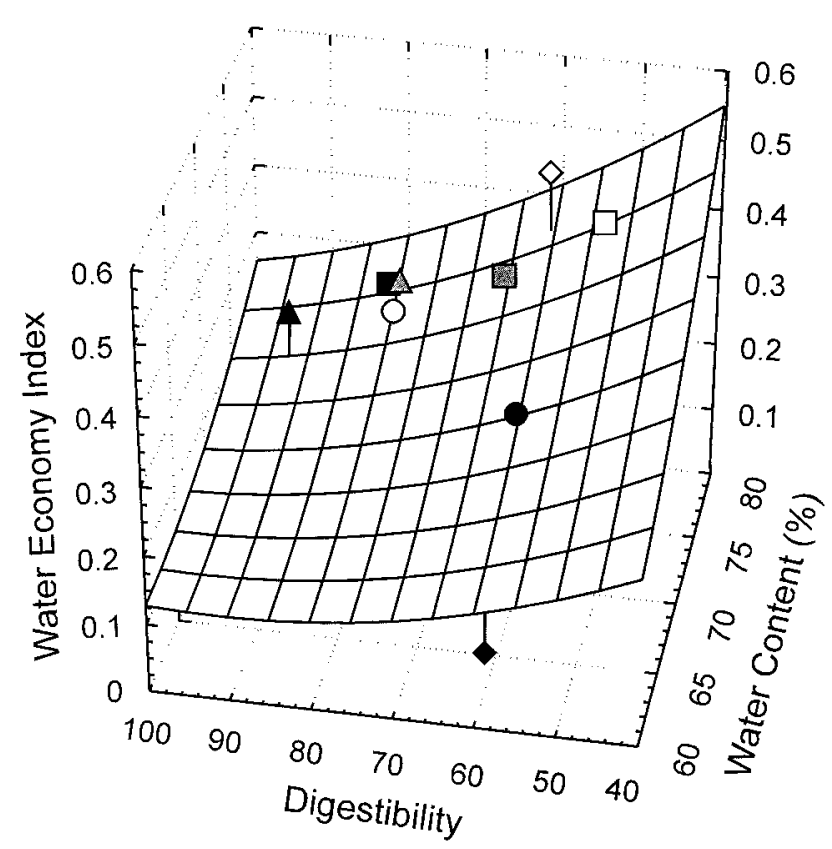

Figure 4. Water economy index for myrmecophagous mammals and reptiles, projected to the theoretical values for a termite/ant diet of 23 $\mathrm{kJ} \mathrm{g}_{\mathrm{dry}}^{-1}$. The numbat is represented with a square (filled square, Coptotermes sp. diet; grey square, Nasutitermes sp. diet; open square, wild numbats), the aardwolf with a triangle (filled triangle, reported data; grey triangle, average energy and water content of Coptotermes and Nasutitermes), the echidna with a filled circle, the silky anteater an open circle, the thorny devil with a filled diamond, and the skink Eremias lugubris with an open diamond. Note that the data are projected to the theoretical values for a $23 \mathrm{~kJ} \mathrm{~g}^{-1}$ diet, but the actual dietary energy content varies slightly from this. 
(K. A. Nagy and G. G. Montgomery, unpublished data) that eat ants have a WEI of 0.19. Their FWTR of $21.2 \mathrm{~mL} \mathrm{H}_{2} \mathrm{O} \mathrm{d}^{-1}$ consists of $18.4 \mathrm{~mL}$ of preformed $\mathrm{H}_{2} \mathrm{O} \mathrm{d}^{-1}$ (MWP $=2.7 \mathrm{~mL}$ $\mathrm{H}_{2} \mathrm{O} \mathrm{d}^{-1}$ ). This would be accompanied by $5.8 \mathrm{~g}$ of solids (ants, $76 \%$ water), which would yield $138 \mathrm{~kJ} \mathrm{~d}^{-1}$ for ants containing $23.9 \mathrm{~kJ} \mathrm{~g}_{\text {dry. }}^{-1}$. Digestibility is therefore $80 \%$ (110/138; Fig. 4).

Echidnas (data from Green et al. 1992), feeding on a mixed diet of $70 \%$ ants and $30 \%$ termites by mass, have a WEI of 0.19 . Their FWTR of $164 \mathrm{~mL} \mathrm{H}_{2} \mathrm{O} \mathrm{d}^{-1}$ consists of $142.4 \mathrm{~mL}$ $\mathrm{d}^{-1}$ of preformed water $\left(\mathrm{MWP}=21.8 \mathrm{~mL} \mathrm{H}_{2} \mathrm{O} \mathrm{d}^{-1}\right)$. This would be accompanied by $66 \mathrm{~g}_{\text {dry }}^{-1}$ solids (termites $72 \%$; ants $65 \%$ water content), which with an energy content of $23 \mathrm{~kJ}$ $\mathrm{g}_{\text {dry }}^{-1}$ is equivalent to $1,516 \mathrm{~kJ} \mathrm{~d}^{-1}$. To sustain FMR $\left(875 \mathrm{~kJ} \mathrm{~d}^{-1}\right)$, the digestibility of a mixed ant and termite diet for echidnas is calculated to be $58 \%$ (Fig. 4). The proportion of ants and termites consumed by echidnas changes seasonally, with more termites being eaten in summer months, which presumably increases the WEI when free water is unavailable (AbenspergTraun and de Boer 1992). Termites yield a higher WEI than ants because of their higher water contents but similar digestibility (see Fig. 3).

Aardwolves (Proteles cristatus; data from Williams et al. 1997 for winter) feed exclusively on termites (consuming $76 \%$ worker and $24 \%$ soldier termites) and have a WEI of 0.21 . Their FWTR of $615 \mathrm{~mL} \mathrm{H}_{2} \mathrm{O} \mathrm{d}^{-1}, 540.7 \mathrm{~mL} \mathrm{~d}^{-1}$ of which is preformed water $\left(\mathrm{MWP}=74.3 \mathrm{~mL} \mathrm{H}_{2} \mathrm{O} \mathrm{d}^{-1}\right)$, is accompanied by $175 \mathrm{~g}_{\text {dry }} \mathrm{d}^{-1}$ (workers $=3.6 \mathrm{mg}_{\text {wet }}$ individual ${ }^{-1}$ and $76.3 \%$ is water; soldiers $=1.9 \mathrm{mg}_{\text {wet }}$ individual ${ }^{-1}$ and $71 \%$ is water), which provides $3,002 \mathrm{~kJ} \mathrm{~d}^{-1}$ (workers $=17 \mathrm{~kJ} \mathrm{~g}_{\text {dry }}^{-1}$ and soldiers $=17.7 \mathrm{~kJ} \mathrm{~g} \mathrm{~g}_{\text {dry }}^{-1}$ ). However, for their measured FMR of $2,891 \mathrm{~kJ} \mathrm{~d}^{-1}$, aardwolves would have to digest $96 \%$ of the calculated ingested energy. This seems unlikely because even dry seed and vertebrate flesh are only around 90\% digestible (Grodzinski and Wunder 1975; Hume 1982; Withers 1982; Green and Eberhard 1983) and suggests some error in measurement of FMR or FWTR for aardwolves or, as is more likely, an error in the measurement of the energy and/or water content of the termites they were feeding on. If we assume the same energy and water contents of the termites as measured in this study (23 $\mathrm{kJ} \mathrm{g}_{\text {dry }}^{-1}$ and $77.4 \% \mathrm{H}_{2} \mathrm{O}$ ), then the aardwolves' digestibility is calculated as $79 \%$ (Fig. 4), which is similar to that measured for captive numbats eating Coptotermes.

For the Kalahari lizard Eremias lugubris (data from Nagy et al. 1984), feeding on an invertebrate diet of $80 \%$ termites, preformed water from the food (FWTR of $0.285 \mathrm{~mL} \mathrm{H}_{2} \mathrm{O}$ $\mathrm{d}^{-1}-\mathrm{MWP}$ of $0.02 \mathrm{~mL} \mathrm{H}_{2} \mathrm{O} \mathrm{d}^{-1}$ ) is $0.265 \mathrm{~mL} \mathrm{H}_{2} \mathrm{O} \mathrm{d}^{-1}$, which (for a diet of $78 \% \mathrm{H}_{2} \mathrm{O}$ ) would be accompanied by $0.075 \mathrm{~g}$ of solids. With an energy content of $17.5 \mathrm{~kJ} \mathrm{~g}_{\text {dry }}^{-1}$, this would provide $1.3 \mathrm{~kJ} \mathrm{~d}^{-1}$. Because FMR is $0.8 \mathrm{~kJ} \mathrm{~d}^{-1}$, the digestibility of termites by E. lugubris is $61 \%$, with a WEI of 0.36 (Fig. 4).

A termite/ant digestibility of $60 \%-80 \%$ by numbats and other myrmecophages is typical of invertebrate diets (Nagy et al. 1978), with the estimated digestibility of a generalised insect around $78 \%$ (Bell 1990). The lower digestibility of some ants and termites $(\sim 60 \%)$ presumably reflects their greater sclerotisation and higher chitin content. Although termites (and insects in general) have a lower digestibility than the $80 \%-95 \%$ typical of carnivorous and granivorous diets (Grodzinski and Wunder 1975; Hume 1982; Withers 1982; Green and Eberhard 1983), they have a similar or even higher digestibility than the 50\%-70\% typical of herbivorous diets (Grodzinski and Wunder 1975; Hume 1982). Myrmecophages consequently have a considerably higher WEI than carnivores (0.07-0.17), granivores (0.04), and herbivores (0.15-0.27; Nagy and Peterson 1988), with a WEI of 0.19-0.36; the thorny devil is an exception $(\mathrm{WEI}=0.11)$, reflecting the low water content of its ant diet. The high WEI of myrmecophages would preadapt them to survive in arid environments without having to drink.

If the low BMRs and $T_{\mathrm{b}}$ 's observed for myrmecophagous mammals do indeed reflect a low-energy diet (McNab 1984, 2000; but see Elgar and Harvey 1987; Harvey et al. 1991), then factors other than low digestibility may be important. Soldier termites use a combination of physical (biting) and chemical (noxious secretions) defences to deter predators, so most termitivorous mammals have very short feeding bouts and move to a new site when the ratio of soldier to worker termites becomes intolerable (Lubin and Montgomery 1981; Redford 1987; Abensperg-Traun 1988; Naples 1999). This continual foraging movement increases foraging time and energy expenditure per kilojoule ingested. A slow passage time, which may be necessary to increase the digestibility of termites, decreases the energy assimilated per unit time. Mammalian specialist termitivores are very large in comparison with their prey and use an elongated tongue, coated with copious sticky saliva, to capture and ingest their prey. This imprecise feeding leads to the ingestion of soil, wood, small stones, termite mound, and other indigestible debris that reduces the overall energy density of a meal (Redford and Dorea 1984). We calculate that numbats ingest at least $0.33 \mathrm{~g}$ of dirt for every gram of organic matter they assimilate (but this is an underestimation of total indigestible debris consumed because our calculations account only for ingested inorganic matter, not organic debris).

\section{Acknowledgments}

We are grateful to Perth Zoo, in particular Dr. Terry Fletcher and staff of the Native Species Breeding Program for their assistance, the use of the numbats, the laboratory space, and teaching us how to collect termites. We thank Dr. Tony Friend, Western Australian Department of Conservation and Land Management, for his advice and permission to work with the numbats. Wesley Bancroft and Kelvin Cooper provided invaluable assistance with setting termite drums in the field. We thank Dr. Ken Nagy for his helpful suggestions and for access to unpublished data on silky anteaters. This study was approved 
by the animal ethics committees of both the University of Western Australia and Perth Zoo. It was supported by an Australian Postgraduate Award to C.E.C. and the Australian Governments Cooperative Research Centres Program through funds for Conservation and Management of Marsupials.

\section{Literature Cited}

Abensperg-Traun M.A. 1988. Food preference of the echidna, Tachyglossus aculeatus (Monotremata: Tachyglossidae), in the wheatbelt of Western Australia. Aust Mammal 11:117-123.

Abensperg-Traun M.A. and E.S. DeBoer. 1992. The foraging ecology of a termite- and ant-eating specialist, the echidna Tachyglossus aculeatus (Monotremata: Tachyglossidae). J Zool (Lond) 226:243-257.

Bell G.P. 1990. Birds and mammals on an insect diet: a primer on diet composition analysis in relation to ecological energetics. Stud Avian Biol 13:416-422.

Bequaert J. 1922. The predaceous enemies of ants. Bull Am Mus Nat Hist 45:271-331.

Brainerd E. 1999. Lickety split. Nature 401:757.

Calaby J.H. 1960. Observations on the banded anteater Myrmecobius $f$. fasciatus Waterhouse (Marsupialia), with particular reference to its food habits. Proc Zool Soc Lond 135: 183-207.

Cooper C.E. 2004. Physiological Specialisations of the Numbat, Myrmecobius fasciatus Waterhouse 1832 (Marsupialia: Myrmecobiidae): A Unique Termitivorous Marsupial. PhD thesis. University of Western Australia, Perth.

Cooper C.E. and P.C. Withers. 2004. Ventilatory physiology of the numbat (Myrmecobius fasciatus). J Comp Physiol 174: 107-111.

Cooper C.E., P.C. Withers, and S.D. Bradshaw. 2003. Field metabolic rate and water turnover of the numbat (Myrmecobius fasciatus). J Comp Physiol 173:687-693.

Cooper C.E., P.C. Withers, P.R. Mawson, D.S. Bradshaw, J. Prince, and H. Robertson 2002. Metabolic ecology of cockatoos in the south-west of Western Australia. Aust J Zool 50: 67-76.

Cummins K.E. and J.C. Wuycheck. 1971. Caloric equivalents for investigations in ecological energetics. Int Ver Theor Angew Limnol Verh 18:1-158.

d'Oleire-Oltmanns W. 1977. Combustion heat in ecological energetics: what sort of information can be obtained? Pp. 315324 in I. Lamprecht and B. Schaarschmidt, eds. Applications of Calorimetry in the Life Sciences. Walter deGrayter, Berlin.

Elgar M.A. and P.H. Harvey. 1987. Basal metabolic rates in mammals: allometry, phylogeny and ecology. Funct Ecol 1: 25-36.

Fleay D. 1942. The numbat in Victoria. Vic Nat 59:3-7.

Forbes W.A. 1882. On some points in the anatomy of the great ant-eater (Myrmecophaga jubata). Proc Zool Soc Lond 1882: 287-302.
Friend J.A. 1982. The numbat: an endangered specialist. Aust Nat Hist 20:339-342.

- 1987. Numbat conservation. Bull Zoo Manag 25:2833.

Green B. and F. Eberhard. 1983. Water and sodium intake, and estimated food consumption, in free-living eastern quolls Dasyurus viverrinus. Aust J Zool 31:871-880.

Green B., M. Griffiths, and K. Newgrain. 1992. Seasonal patterns in water, sodium and energy turnover in free-living echidnas, Tachyglossus aculeatus (Mammalia: Monotremata). J Zool (Lond) 227:351-365.

Griffiths M. 1965. Digestion, growth and nitrogen balance in an egg-laying mammal, Tachyglossus aculeatus (Shaw). Comp Biochem Physiol 14:357-375.

- 1968. Echidnas. Pergamon, Sydney.

Grodzinski W. and B.A. Wunder. 1975. Ecological energetics of small mammals. Pp. 173-204 in F.B. Golley, K. Petrusewicz, and L. Ryszkowski, eds. Small Mammals: Their Productivity and Population Dynamics. Cambridge University Press, London.

Harvey P.H., M.D. Pagel, and J.A. Rees. 1991. Mammalian metabolism and life histories. Am Nat 137:556-566.

Hubert B., D. Gillon, and F. Adam. 1981. Cycle annuel du régime alimentaire des trois principales espèces de rongeurs (Rodentia; Gerbillidae et Muridae) de Bandia (Sénegal). Mammalia 45:1-20.

Hume I.D. 1982. Digestive Physiology and Nutrition of Marsupials. Cambridge University Press, Sydney.

Lubin Y.D. and G.G. Montgomery. 1981. Defenses of Nasutitermes termites (Isoptera, Termitidae) against tamandua anteaters (Edentata, Myrmecophagidae). Biotropical 13:66-76.

Maynard L.A. and J.K. Loosli. 1969. Animal Nutrition. McGraw-Hill, Sydney.

McNab B.K. 1984. Physiological convergence amongst anteating and termite-eating mammals. J Zool (Lond) 203:485510.

-2000. Energy constraints on carnivore diet. Nature 407: 584.

Murie J. 1875. On the habits, structure, and relations of the three-banded armadillo (Tolypeutes conurus, Is. Geoff.). Trans Linn Soc Lond 30:71-132.

Nagy K.A. and D.P. Costa. 1980. Water flux in animals: analysis of potential errors in the tritiated water method. Am J Physiol 238:R454-R465.

Nagy K.A., R.B. Huey, and A.F. Bennett. 1984. Field energetics and foraging mode of Kalahari lacertid lizards. Ecology 65: 588-596.

Nagy K.A. and C.C. Peterson. 1988. Scaling of water flux rate in animals. Univ Calif Publ Zool 120:1-172.

Nagy K.A., R.S. Seymour, A.K. Lee, and R. Braithwaite. 1978. Energy and water budgets in free-living Antechinus stuartii (Marsupialia: Dasyuridae). J Mammal 59:60-68.

Naples V.L. 1999. Morphology, evolution and function of feed- 
ing in the giant anteater (Myrmecophaga tridactyla). J Zool (Lond) 249:19-41.

Owen R. 1857. On the anatomy of the great ant-eater Myrmecophaga jubata (Linn.). Pt. 2. Proc Zool Soc Lond 1857: $22-23$.

Oyarzun S.E., G.J. Crawshaw, and E.V. Valdes. 1996. Nutrition of the tamandua. 1. Nutrient composition of termites ( $\mathrm{Na}$ sutitermes spp.) and stomach contents from wild tamanduas (Tamandua tetradactyla). Zoo Biol 15:509-524.

Redford K.H. 1987. Ants and termites as food: patterns of mammalian myrmecophagy. Pp. 349-399 in H.H. Genoways, ed. Current Mammalogy. Vol. 1. Plenum, New York.

Redford K.H. and J.G. Dorea. 1984. The nutritional value of invertebrates with emphasis on ants and termites as food for mammals. J Zool (Lond) 203:385-395.

Seymour R.S., P.C. Withers, and W.W. Weathers. 1998. Energetics of burrowing, running and free-living in the Namib Desert golden mole (Eremitalpa namibensis). J Zool (Lond) 244:107-117.
Tihon L. 1946. A propos des termites au point de vue alimentaire. Bull Agric Congo Belge 37:865-868.

Weber M. 1891. Beiträge zur anatomie und entwickelungs des genus Manis. Zool Ergeb Reise Niederländisch Ost-Indien.

Williams J.B., M.D. Anderson, and P.R.K. Richardson. 1997. Seasonal differences in field metabolism, water requirements, and foraging behaviour of free-living aardwolves. Ecology 78:2588-2602.

Withers P.C. 1978. Bioenergetics of a "primitive" mammal, the Cape golden mole. S Afr J Sci 74:347-348.

- 1982. Effect of diet and assimilation efficiency on water balance for two desert rodents. J Arid Environ 5:375-384.

. 1992. Comparative Animal Physiology. Saunders College, Philadelphia.

Withers P.C. and S.D. Bradshaw. 1995. Water and energy balance of the thorny devil Moloch horridus: is the devil a sloth? Amphib-Reptilia 16:47-54.

Withers P.C. and C.R. Dickman. 1995. The role of diet in determining water, energy and salt intake in the thorny devil Moloch horridus (Lacertilia: Agamidae). J R Soc West Aust 78:3-11. 